\title{
A Concordance of Inscription Titles
}

Many of the inscriptions collected here have been published or referred to under a different title or under multiple titles. While my use of modern Anglicisations of place names (such as Mandsaur instead of the formerly popular Mandasor) should not prevent anyone looking for a particular inscription from finding it, my reference to inscriptions by the name of the person who actually commissioned them (if known), rather than by that of a king who is mentioned in them but was not involved in their creation, may cause some confusion. For clarity's sake I provide the list of previously used inscription titles and their correspondence to section numbers in this book.

\begin{tabular}{|c|c|}
\hline Published title & Number \\
\hline Fragmentary inscription from Chitorgarh & $\mathrm{A} 13, \mathrm{~A} 14$ \\
\hline $\begin{array}{l}\text { Gangdhar (Gangrar, Gangadhar) inscription of } \\
\text { Viśvavarman }\end{array}$ & A4 \\
\hline $\begin{array}{l}\text { Mandasor inscription of Kumāragupta and } \\
\text { Bandhuvarman, the Mālava/Kṛta years } 493 \text { and } 529\end{array}$ & A6 \\
\hline Mandasor inscription of Mālava saṃvat 524 & A5 \\
\hline Mandasor inscription of the Mālava years 493 and 529 & A6 \\
\hline Mandasor inscription of Vikrama saṃvat 589 & A10 \\
\hline Mandasor pillar inscription of Yaśodharman & $\mathrm{A} 11, \mathrm{~A} 12$ \\
\hline Mandasor stone inscription of the time of Prabhākara & A5 \\
\hline $\begin{array}{l}\text { Mandasor stone inscription of Yaśodharman } \\
\text { (and Vișṇuvardhana), the Mālava year } 589\end{array}$ & A10 \\
\hline
\end{tabular}


